\title{
Nest and nestling description of Automolus rufipileatus from Brazil
}

\author{
Tiago Guimarães Junqueira ${ }^{1,4}$, Kelrene Moreira Lara' ${ }^{2}$ João Batista Pinho ${ }^{2}$, Mônica Aragona ${ }^{3}$, \\ Pablo Vinícius Clemente Mathias ${ }^{1} \&$ Claudio Veloso Mendonça ${ }^{1}$
}

\author{
Biota Projetos e Consultoria Ambiental LTDA., Goiânia, GO, Brazil. \\ 2 Laboratório de Ornitologia, Núcleo de Estudos Ecológicos do Pantanal, Instituto de Biociências, Universidade Federal de Mato Grosso (UFMT), \\ Cuiabá, MT, Brazil. \\ 3 Faculdade de Engenharia (CUVG), Universidade Federal de Mato Grosso (UFMT), Cuiabá, MT, Brazil. \\ ${ }^{4}$ Corresponding author: tiagoguimaraes27@yahoo.com.br
}

Received on 13 May 2019. Accepted on 02 September 2019.

\begin{abstract}
We describe here the first documented nest and nestling of the Chestnut-crowned Foliage-gleaner (Automolus rufipileatus) in Brazil. They were recorded in the municipality of Vitória do Xingu, state of Pará, at Amazonian domains. As other members of the genus Automolus, the nest of A. rufipileatus was in a steep clay bank on the edge of a small stream, comprising an inclined entrance tunnel to access two distinct chambers. The nest can be classified as a cavity with inclined tunnel. When discovered, the nest housed a nestling in advanced stage of development; therefore, it was not possible to describe the eggs, incubation period and nestling's initial development. We encourage additional studies on Chestnut-crowned Foliage-gleaner reproductive biology.
\end{abstract}

KEY-WORDS: Amazonian Forest, Furnariidae, life history, reproductive biology, Xingu River.

Nowadays, there are 35 genera and 105 species of Furnariidae birds recognized in Brazil (Piacentini et al. 2015). The family presents a great diversity of architectural nests with more than 20 distinct forms of construction, ranging from tangles of sticks, as in genera Synallaxis and Phacellodomus, to constructions in steep banks, as in the genus Automolus (Zyskowski \& Prum 1999). Nine species of Automolus are known to Brazil (Piacentini et al. 2015), A. rufipileatus, A. melanopezus, A. cervicalis, A. subulatus, A. ochrholaemus, A. infuscatus, $A$. paraensis, A. lammi and A. leucophthalmus. However, there is a lack of information about the behavior, territory, and, specially, reproductive biology of these species, except for $A$. ochrolaemus (Van Tyne 1926, Skutch 1952), A. leucophthalmus (Marini et al. 2007) and A. paraensis (del Hoyo et al. 2018).

Based on previous studies, the nests found for all species of Automolus genus exhibit the same pattern: they are cavities in the soil, usually in steep banks bordering small streams (Van Tyne 1926, Marini et al. 2007). Because of this reproductive behavior, Automolus species are commonly known as "barranqueiros" in Brazil, which means, in a free translation, those who use steep banks for nesting. Specifically, Londońo (2014) reported photographs of $A$. rufipileatus eggs and nests. However, Londoño (2014) did not describe the dimensions of the nest and eggs, or the environment surrounding the nest and, probably for this reason, Remsen-Jr. (2018) considered that this species' nest was not described. From Londoño (2014) it is possible to check (through the investigation of photographs) that the nest follows the same pattern described in the present study, occurring in burrows in soil, and the eggs are white and ovoid.

Automolus rufipileatus is a resident species and it is distributed across South America, including Bolivia, Colombia, Ecuador, Peru, Guyana, French Guiana, Suriname, Venezuela, and Brazil (Birdlife International 2017, Remsen-Jr. 2018). Records in Brazil are exclusive to the Amazonian domain, where two subspecies are recognized: A. r. consobrinus and A. r. rufipileatus. The latter occurs south of the Amazon River (Remsen-Jr. 2018) and in the Volta Grande do Xingu, Pará state.

Life history of the species is virtually unknown, with little information regarding its habitat and food. According to Remsen-Jr. (2018), the species is insectivorous and forages by turning over dried leaves and litter; they can be seen in pairs and eventually in mixed flocks. They inhabit wetlands, alluvial forests and terra firme environments with presence of bamboo (Sick 1997, Remsen-Jr. 2018). This work aims to present information concerning the reproductive biology of A. rufipileatus, through description of a nest and a nestling observed in the municipality of Vitória do Xingu (Volta Grande do Xingu), state of Pará.

On 17 February 2015, during the rainy season, a nest 
of Chestnut-crowned Foliage-gleaner was found $80 \mathrm{~cm}$ above the ground inside the soil walls of a steep bank of a small stream "igarapê" in terra firme forest (Fig. 1A), with Açai Palm Trees (Euterpe oleracea) bordering the stream ( $3^{\circ} 19^{\prime} 54^{\prime \prime}$; 5 52 ${ }^{\circ} 6^{\prime} 29^{\prime \prime W}, 213 \mathrm{~m}$ a.s.l). The nest was housing a single nestling, which was in a pinfeather stage. The nest was composed of an inclined-up access tunnel, with dimensions $7 \mathrm{~cm}$ height, $6 \mathrm{~cm}$ width and $20 \mathrm{~cm}$ depth, measured with a ruler (Fig. 1B \& C), conducting to two chambers in a line sequence. The first chamber was wider and flattened $(9 \times 15 \times 10 \mathrm{~cm}$ approximately - chamber 1), and the second chamber was smaller and basket-shape $(6 \times 9 \times 8 \mathrm{~cm}$ approximately - chamber 2; Fig. 1C). Because of the difficulty in measuring the cavities due to the format and dimensions of the access tunnel, the measures of the chambers were estimated. Both chambers were lined with rootlets, but chamber 2, which was housing the nestling, had a thicker layer suggesting it was the place where eggs were incubated. We found fecal bags excreted by the chick in chamber 1 (Fig. 2A) and it

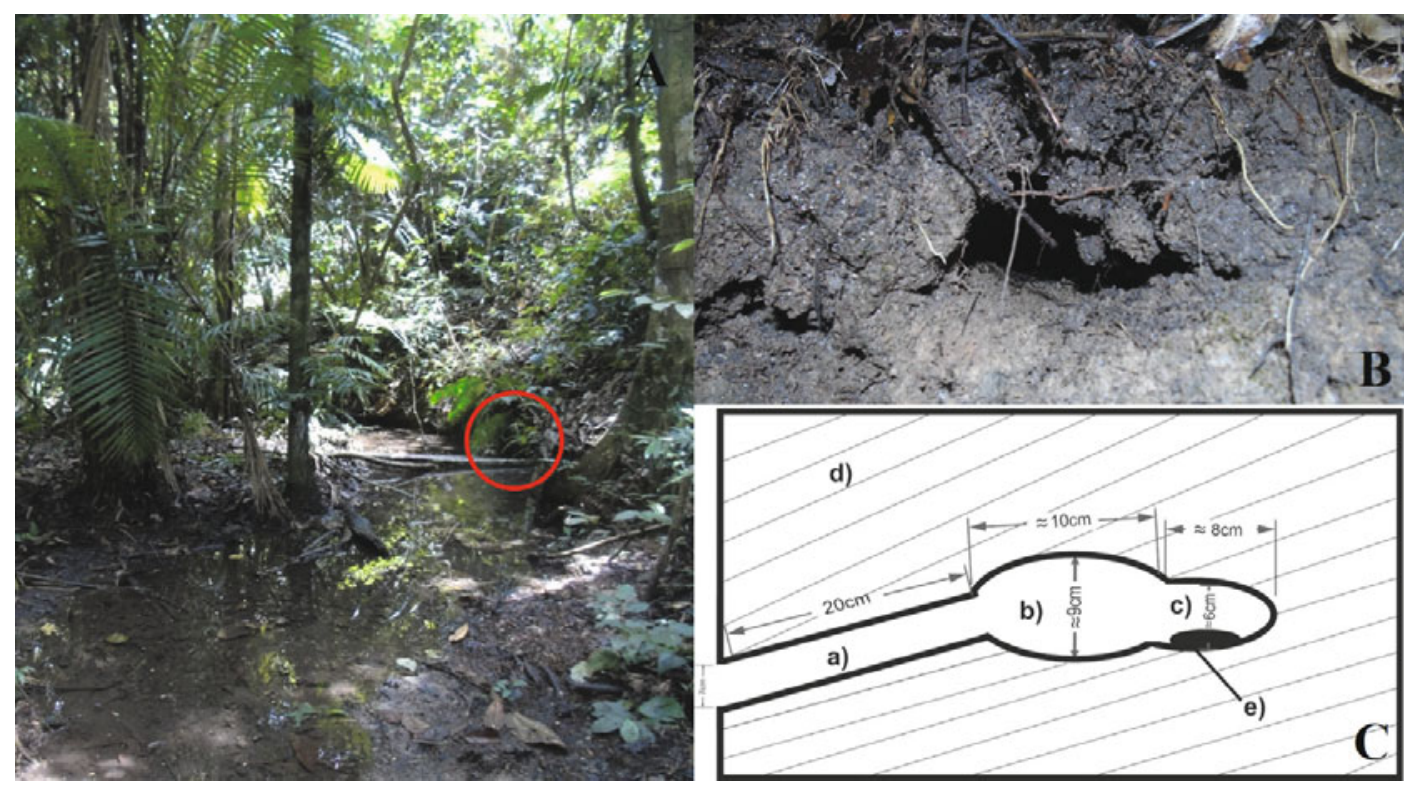

Figure 1. Terra firme forest where the nest of Automolus rufipileatus was found (A). Entrance of the access tunnel of $A$. rufipileatus nest (B). Sketch of $A$. rufipileatus nest, in a longitudinal cut (C), showing a) access tunnel; b) chamber one; c) chamber two; d) soil texture surrounding the nest; and e) rootlets thicker layer in basket-shape inside chamber two.

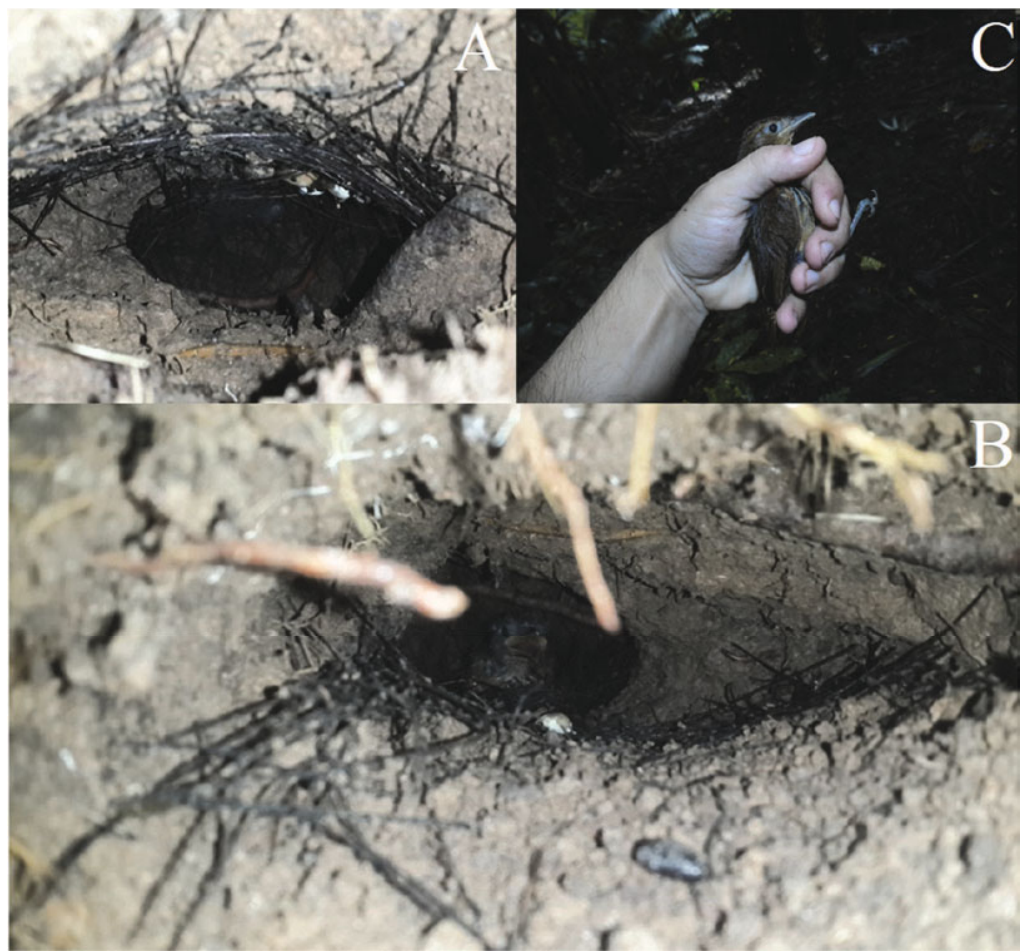

Figure 2. The interior of an Automolus rufipileatus nest: in the foreground the chamber one with nest garbage (A). Nestling inside the chamber two in the first visit (B). Nestling in the third visit $(\mathbf{C})$. 
is plausible to assume that these fecal bags were moved from chamber 2 to chamber 1 by adults. Unfortunately, the fecal bag removal event was not observed over $10 \mathrm{~h}$ of observations. However, three fecal bags were removed between our first (17 February) and second (18 February) visits to the nest.

The single nestling found in the nest during the first visit presented few down feathers and reddish-brown emerged pinfeathers of developing wings and tail feathers (Fig. 2B). In the third visit (24 February), we observed that the nestling had already developed the uniform reddish-brown plumage, coating practically the whole body (Fig. 2C), and it was ready to leave the nest. During this visit, we collected biometrical data (wing $=6.1 \mathrm{~cm}$, tail $=4.2 \mathrm{~cm}$, tarsus $=2.2 \mathrm{~cm}$, beak length $=1.7 \mathrm{~cm}$, total length $=14.2 \mathrm{~cm}$ ) and banded the nestling, which had a darkish rufescent-brown plumage. In the fourth visit (27 February), the nestling was not found inside the nest and it was not observed again. In two visits, we saw an adult in the vicinity of the nest a few times, and on all occasions only one adult was seen at a time, always in a silent and discreet approach.

The nest of the Chestnut-crowned Foliage-gleaner follows the same pattern observed for other species of the genus, in which nests are built in steep bank, with cavityshaped tunnels, bordering water bodies (Van Tyne 1926, Skutch 1952, Marini et al. 2007). The classification of the nest of $A$. rufipileatus, based on Simon \& Pacheco (2005), is cavity/with-tunnel/simple/platform, although the nest described here is not effectively contemplated by this classification because it presents two chambers after the access tunnel. Remsen-Jr. (2018) reported two males in breeding condition in February in Venezuela, the same period of reproduction confirmed in this study. Both studies registered the same reproductive period for the species.

Our study reports some new information on the life history of the Chestnut-crowned Foliage-gleaner and the first documented nest of the species in Brazil. We believe that the records presented here may help other ornithologists with the discovery of other nests of Chestnut-crowned Foliage-gleaner, in earlier stages of development (building the nest, posture and hatching eggs), therefore, leading to an increase in our knowledge on the natural history and reproductive biology of this species. Such information may be key for conservation actions, especially for Amazonian species, which are constantly threatened by increasing deforestation.

\section{ACKNOWLEDGEMENTS}

We thank the companies Biota Projetos e Consultoria Ambiental LTDA. and Norte Energia S.A. responsible for providing financial resources that allowed us to conduct this study in Volta Grande do Xingu, Pará, Brazil.

\section{REFERENCES}

BirdLife International. 2017. The IUCN red list of threatened species [Automolus rufipileatus]. http://dx.doi.org/10.2305/IUCN. UK.2017-1.RLTS.T22702946A110876695.en (Access on 05 November 2018).

del Hoyo J., Collar N. \& Kirwan G.M. 2018. Foliage-gleaner (Automolus paraensis). In: del Hoyo J., Elliott A., Sargatal J., Christie D.A. \& de Juana E. (eds.). Handbook of the birds of the world alive. Barcelona: Lynx Editions. https://www.hbw.com/ species/para-foliage-gleaner-automolus-paraensis (Access on 04 November 2018).

Londoño G.A. 2014. Parque Nacional del Manu, Cusco, Perú: anidación de aves en un gradiente altitudinal. Chicago: The Field Museum.

Marini M.A., Aguilar T.M., Andrade R.D., Leite L.O., Anciáes M., Carvalho C.E.A., Duca C., Maldonado-Coelho M., Sebaio F. \& Gonçalves J. 2007. Biologia da nidificação de aves do sudeste de Minas Gerais, Brasil. Revista Brasileira de Ornitologia 15: 367-376.

Piacentini V.Q, Aleixo A., Agne C.E., Maurício G.N., Pacheco J.F., Bravo G.A., Brito G.R.R., Naka L.N., Olmos F., Posso S., Silveira L.F., Betini G.S., Carrano E., Franz I., Lees A.C., Lima L.M., Pioli D., Schunck F., do Amaral F.R., Bencke G.A, Cohn-Haft M., Figueiredo L.F.A., Straube F.C. \& Cesari E. 2015. Annotated checklist of the birds of Brazil by the Brazilian Ornithological Records. Revista Brasileira de Ornitologia 23: 91-298.

Remsen-Jr. J.V. 2018. Chestnut-crowned Foliage-gleaner (Automolus rufipileatus). In: del Hoyo J., Elliott A., Sargatal J., Christie D.A. \& de Juana E. (eds.). Handbook of the birds of the world alive. Barcelona: Lynx Editions. https://www.hbw.com/species/ chestnut-crowned-foliage-gleaner-automolus-rufipileatus (Access on 03 March 2018).

Sick H. 1997. Ornitologia brasileira. Rio de Janeiro: Editora Nova Fronteira.

Simon J.E. \& Pacheco S. 2005. On the standardization of nest descriptions of Neotropical birds. Revista Brasileira de Ornitologia 13: $143-154$.

Skutch A.F. 1952. Life history of the Chestnut-tailed Automolus. Condor 54: 93-100.

Van Tyne J. 1926. The nest of Automolus ochrolaemus pallidigularis Lawrence. Auk 43: 546.

Zyskowski K. \& Prum R.O. 1999. Phylogenetic analysis of the nest architecture of Neotropical ovenbirds (Furnariidae). Auk 116: 891-911.

Associate Editor: Eduardo S. Santos. 